New Zealand Geological Survey, and was appointed Director after the resignation of J. M. Bell in 1911.

He was by training and inclination a mining geologist, and under his direction, and through his activities in the field, there appeared a succession of bulletins dealing primarily with the coal and gold resources of the Dominion. At the same time, by his sympathetic co-operation, J. A. Thomson was able to inaugurate a series of palaeontological bulletins which have placed New Zealand palaeontology on a firm basis.

P. G. Morgan was by nature cautious, thorough, and painstaking. $\mathrm{He}$ had a wide knowledge of geological literature and thought, and a high ideal of the functions of a state geological survey.

R. S. Allan.

\title{
Wilhelm von Branca.
}

Born 9Th Seftember, 1844.

Died 12Th MARCh, 1928.

With Wilhelm von Branca one of the most prominent German geologists has passed away. The active part of his life is now somewhat remote, for he retired more than ten years ago (1917). Thus for the younger generation his geological work has more of an historical nature, but it is our duty to pay tribute to the fame of a great master whose name will always be associated with vulcanology and matters connected therewith.

Wilhelm von Branca was born in 1844 at Potsdam, near Berlin. He studied at Greifswald, Halle, Heidelberg, Rome, Berlin, Strassburg and Munich. He graduated at Heidelberg (Dr. phil.) and Tuebingen (Dr. rer. nat.) in 1876. In the same year he became a demonstrator in Mineralogy at Heidelberg, 1881. He began his career as lecturer in Berlin, in the same year in Aachen. One year later he joined the Geological Survey at Berlin. In 1887 he was made a Professor of Mineralogy at Koenigsberg and fulfilled the same function from 1890 to 1895 at Tuebingen and 1895 to 1899 at Hohenheim. He was then called to Berlin as the successor to Leopold von Buch. He taught geology here up to 1917, when he retired and was succeeded by J. F. Pompeckj. His work, the fruit of strenuous untiring effort, won for him recognitions both at home and abroad. Thus he was made a "Geheimer Bergrath" in 1898, an honorary Doctor of several German universities, and was elected a Fellow of the Royal Academies of Berlin and St. Petersburg.

Practically in all branches of geological work Branca has left great contributions. His Doctorate thesis dealt with the volcanoes of the Herniker district (Italy) and vulcanism remained his favourite subject. Among the most important publications which were partly of a mere theoretical and partly of stratigraphical nature two works are especially outstanding, both of which have shown new ways to 
geology. These were The Embryonal Volcanoes of Suabia (Schwabens 125 Vulkanembryonen), 1892-8, and his theories on the origin of the Ries of Noerdlingen and the neighbouring cryptovolcanic basin of Steinheim (1901-1913). The latter were frequently atacked (Koken, Penck, Kranz, etc.) and even to-day after thirty years this greatest riddle of German geology is still the centre of exciting discussions. Nevertheless if the theories have changed the fundamental work was done by Branca.

In palaeontology his main work was on the development of the Ammonites, on fossil fish and the origin of man. He organized the great Tendaguru Expedition to former German East Africa, the results of which are now to be seen at the Natural History Museum of Berlin and remain an indissoluble monument to this great. geologist.

Herbert P. T. Rohleder.

\section{CORRESPONDENCE.}

TO ALL THOSE INTERESTED IN ECONOMIC GEOLOGY.

SIR,-This is an earnest appeal for help towards establishing an Annotated Bibliography of the International Literature of Economic Geology.

No country is sufficient unto itself and least of all in science. All geologists probably realize this ; and those who employ geologists should likewise realize that the efficiency of their staff is largely dependent upon familiarity with the progress of science throughout the world. We can not afford isolation or imperfect knowledge. A plan worked out by the Division of Geology and Geography of the National Research Council at Washington for such an Annotated International Bibliography has been approved by the Council itself, the U.S. Geological Survey, the U.S. Bureau of Mines, the American Institute of Mining and Metallurgical Engineers, and the Society of Economic Geologists.

The plan includes a subscription fund of at least $\$ 18,000$, which will provide means for the editorial work for from five to seven years. The National Research Council has agreed to serve as treasurer and custodian of these funds, to be expended in accordance with the usual customs of the Council. Tentative arrangements have been made with an experienced bibliographer to take charge of the work. The Economic Geology Publishing Company has agreed to publish the bibliography, which is to be issued in two volumes per year, aggregating about 400 pages, and to sell it for an equitable price, which will probably be about $\$ 2.50$ per volume, which should pay for paper, printing, and distribution.

It will be observed that the present plan is restricted to economic geology and calls for funds to carry on the work for a limited time only, but it is felt that it will prove so useful, indeed, so indispensable, 